\title{
Characteristics of Intrapreneurs in Scale-Intensive Service Firms
}

\author{
Katja Maria Hydle*, Tor Helge Aas ${ }^{* *}$ \\ and Karl Joachim Breunig ${ }^{* * *}$
}

\begin{abstract}
This empirical paper explores the work of employees in charge of service innovation when firms develop and launch new scale-intensive services by addressing two research questions: i) How do employees responsible for service innovation work? and ii) what are the related managerial implications when developing and launching new scale-intensive services? To this end, 21 qualitative, in-depth interviews were conducted with employees in five large scale-intensive service firms. The findings suggest that the involvement of internal professionals is an asset when new scale-intensive services are developed, and that internal professionals act as intrapreneurs when they are involved in the development of radically new scale-intensive services. This paper integrates understanding from the innovation management literature with knowledge of professionals from extant literature on professional service firms since we find that professionals in scale-intensive firms act as intrapreneurs. Thus, this paper extends the theory on determinants of innovation in scale-intensive service firms, blending insights from both findings and theory.

Keywords: innovation management, service innovation, scale-intensive services, intrapreneurship.
\end{abstract}

\section{INTRODUCTION}

This paper reveals how internal professionals are central for innovation work in scale-intensive service firms. Scale-intensive services are standardized services that are produced at a large scale, mainly by large firms. Examples include bank, insurance, telecommunication, and logistics services (De Jong, Bruins, Dolfsma, \& Meijgaard, 2003; Pavitt, 1984). These services have some characteristics that distinguish them from other services: for example, they are

\footnotetext{
* Katja Maria Hydle, senior research scientist, International Research Institute of Stavanger, Oslo Science Park, Gaustadalleen 21, 0349 Oslo, Norway, katja.hydle@iris.no.

** Tor Helge Aas, Ph.D., associate professor, School of Business and Law, University of Agder, Gimlemoen 19, 4630 Kristiansand, Norway, tor.h.aas@uia.no.

*** Karl Joachim Breunig, Ph.D., associate professor, School of Business, Oslo and Akershus University College of Applied Sciences, Postboks 4, St. Olavs plass, 0130 Oslo, Norway, karl.joachim.breunig@hioa.no.
} 
often dependent on physical networks or information- and communicationtechnology (ICT) networks (Soete \& Miozzo, 1989).

Insights into how scale-intensive service firms innovate successfully is of relevance also for firms in other service sectors that partly follow a standardization strategy (Hansen, Nohria, \& Tierney, 1999). This is because service firms that do not traditionally belong to the scale-intensive services category also experience pressure to achieve greater uniformity and standardization (Ellingsen, Monteiro, \& Munkvold, 2007). This trend is increasing in both knowledge-intensive services, such as legal and consultancy services (Sako, 2009), and supplier-dominated service sectors, such as tourism services (Casadesus, Marimon, \& Alonso, 2010).

The existing innovation management research has highlighted a number of determinants of innovation in scale-intensive firms without focusing on the particular role of employees with specialized knowledge and their role in innovation projects. Therefore, we address the role of internal employees when they are involved in service innovation processes in the scaleintensive service firms where they are employed. Moreover, since our focus is particularly on employees rather than on top managers, who deal with service innovation within scale-intensive firms, we ask the following research questions: i) How do employees responsible for service innovation work? and ii) how can managers facilitate service innovation work in scale-intensive firms? The contribution of this paper is to bridge the literature on innovation management with the findings that draw on insights from professional service firm (PSF) theory with the understanding of professionals and their work. PSFs include among others law firms, management consultant firms and engineering consultants, where the work is characterised as highly knowledge intensive, involving customization and personal judgement and delivered according to professional norms of conduct (Løwendahl, 2005). We build on extant research on professions and professional service firms to structure our empirical investigation into how professionals perform innovation activities in the observed scale intensive service firms.

The remainder of this article is organized as follows. The next section presents the related theoretical background from the available literature on innovation management. A section on the research design is followed by empirical findings from five scale-intensive firms. Next, the findings are discussed and the last section provides a summary of the findings with contributions and limitations. 


\section{LITERATURE REVIEW}

To address the two research questions, we draw on insights from both innovation management research and research on professional service firms (Greenwood and Empson, 2003; Løwendahl, 2005; Von Nordenflycht, 2010). In innovation management, researchers have investigated how innovation in services should be managed, often referring to new service development (Castro, Montoro-Sanchez and Ortiz-De-Urbina-Criado, 2011; Heusinkveld and Benders, 2002; Menor and Roth, 2007; Sundbo, 1997; Toivonen and Tuominen, 2009). The study of relevant drivers for successfully developing new services, so-called success factors for innovation in services, has emerged as one of the most important topics in this research stream (Droege, Hildebrand and Forcada, 2009). The literature suggests several success factors for service innovation, including: the co-workers of service firms and their knowledge (De Jong et al., 2003); the existence of a development staff with knowledge about the firm's technologies, customers, and delivery processes (Drew, 1995; Fischer, Garrelfs and van der Meer, 1993); and the presence of certain key roles, such as decision makers, project leaders, sponsors, and ambassadors (De Jong et al., 2003). These success factors have primarily been discussed relative to innovation in knowledge-intensive business services (Amara, Landry and Doloreux, 2009) or PSFs (Leiponen, 2005), but neglected in other service sectors (Droege et al., 2009). Consequently, relatively little is known about the role of professionals (i.e., co-workers with specialized knowledge) who are internally involved when service firms launch innovative service offerings to the market.

This literature gap causes concern, given the diversity of the service sectors (De Jong et al., 2003; Zomerdijk and Voss, 2011), which range from scale-intensive and consumer markets to expert advice and individual clients. Projects performed in different service sectors are expected to require very different resources (MacCormack and Verganti, 2003), and the role of internal professionals may vary significantly between service sectors.

In a study of service firms, Sundbo identifies three paradigms for understanding innovation in service firms (Sundbo, 1997). The first paradigm is technological development, which is often organized in R\&D departments. According to Sundbo, this paradigm is not relevant to service firms since he stresses that most innovation in service firms happens in ad hoc project groups and is not necessarily linked to technology development. The second paradigm is entrepreneurship or intrapreneurship within organizations (Pinchot, 1985). However, since entrepreneurship is related to the establishment of new firms, and intrapreneurship is hard to manage, Sundbo does not consider this second paradigm to be very relevant to service firms. The third and most 
apt paradigm is connected to how a firm's strategy is the core determinant of innovation.

Sundbo presents an empirically derived taxonomy regarding the organization and management of innovation in service firms (Sundbo, 1997). Scale-intensive firms are understood to be top-strategic organizations, in which the top-manager may be an intrapreneur. Intrapreneurs are managers or employees that transform ideas into new or improved products and services in their organization (Pinchot, 1985; Pinchot and Pellman, 1999). Tourist firms are organized as network organizations. Finally, PSFs are viewed as professional organizations, either as a collective of professionals or representing entrepreneurs. The role of the top managers is emphasized in scale-intensive firms, whereas the role of professionals is more accentuated in PSFs. From Sundbo's study we can derive that in scale-intensive firms, top managers operate as intrapreneurs, while in PSFs the professionals are involved in innovation activities.

Although top managers are understood as intrapreneurs, the understanding of professionals from PSF theory may be informative to our study since they, according to Sundbo, are in charge of service innovation activities when working for PSFs (Løwendahl, 1997; Maister, 1993; von Nordenflycht, 2010). In PSFs, relatively few professionals work on service innovation internally, because most projects are tailor-made to customer needs. As Løwendahl (2005) indicates, PSFs often have a high degree of innovation when developing new concepts and solutions for clients (2005: 39). Some studies have explored the process of new concept development in contexts other than projects for clients in PSFs, focusing on the related internal key activities and managerial tensions (Heusinkveld and Benders, 2002; Heusinkveld and Benders, 2005). The findings show that the process of developing new concepts: i) exposes tensions between the needs for a disciplined corporate approach and individual professional autonomy (Heusinkveld and Benders, 2002), and ii) requires persuasive skills to gain organizational support (Heusinkveld and Benders, 2005).

Empirical research on the roles and functions of professionals outside of PSFs has been underemphasized. There is some research available concerning 'internal consulting', in which an understanding of external management consulting is used internally within a firm (Johri, Cooper and Prokopenko, 1998; Lacey, 1995; Lacey and Tompkins, 2007; Wright, 2008, 2009). These studies have focused on identifying firms that employ internal consulting (Wright, 2009), as well as elucidating how internal consultants promote and implement changes internally (Johri et al., 1998; Lacey, 1995) and how they manage their external counterparts as active clients (Sturdy and Wright, 2011). However, this research stream does not address how internal consultants or 
professionals are involved in innovation processes when they are employed by service firm types other than PSFs.

To further understand the professionals, we turn to PSF theory. Professionals contribute their skills, expertise, experiences, relationships, professional reputations, and networks to the firms (Greenwood, Li, Prakash and Deephouse, 2005; Løwendahl, 2005). A central characteristic of professionals is their mastery of a particular expertise or knowledge base (von Nordenflycht, 2010, p. 156). Professionals follow the core professional norm (von Nordenflycht, 2010) of exhibiting altruistic service by having responsibility towards their clients and protecting their interests (Løwendahl, 2005) or trusteeship (Greenwood et al., 2005). The notion of altruism is related to the strong professional norms that guide conduct in professions that are subject to a high degree of autonomy i.e. the expectation towards a doctor or a lawyer to put self-interest aside for the best of their client (Abbott, 1988). Moreover, the notion of altruism is related to shared professional norms and values and far extends a traditional customer-orientation. In the case of conflicting demands between what is the best solution for the customer versus what is most profitable for the service provider, altruistic service means that customer-centric solution will be applied (Løwendahl, 2005). Further, professionals show a preference for autonomy (Alvesson and Karreman, 2006), exhibiting a distaste for control, supervision, and formal organizational processes (Greenwood and Empson, 2003; Løwendahl, 2005; von Nordenflycht, 2010). Moreover, successful professionals learn and display knowledge and appropriate behaviour through networking (Anderson-Gough, Grey and Robson, 2000). Networking is the outcome of a socialization process through which 'how things work' and 'what is appropriate' are learned (Anderson-Gough et al., 2000, p. 239). Direct supervision is of little use in PSFs, because the manager may know less about a topic than the professional experts they are set to supervise ( $\llcorner\varnothing w e n d a h l, 2005)$. In this case, detailed and direct instructions are fruitless. Thus, informal management processes may be more useful than formal processes in PSFs (von Nordenflycht, 2010). For managers, managing people that make their own decisions is referred to as the challenge of 'herding wild cats' (Løwendahl, 2005, p. 69), where the term 'wild cats' refers to the characteristics of highly individual professionals. According to Løwendahl (2005), professionals are members of a highly professionalized group, have higher education, emphasize the use and development of knowledge, respect core professional norms, and participate in peer reviews (Løwendahl, 2005, p. 28). Being a professional is, therefore, not synonymous with being a 'wild cat', although the management of knowledgeable experts may be challenging. This concept includes dealing 
with professionals who suggest ideas that extend beyond the firm's strategy (Løwendahl, 2005).

Thus, according to PSF literature, professionals use their expertise to provide altruistic services; they prefer autonomy and learn through networking. To manage these professionals, informal processes are most apt. These insights are highly relevant for our study on how employees within scale-intensive service firms work in relation to service innovation and how managers can facilitate their work. In the next section we describe the research design and methods used in this study to explore in-house service innovation by employees.

\section{RESEARCH METHODS}

In this study, we aimed to understand how employees in scale-intensive firms work with service innovation. We conducted interviews with partly open-ended questions related to the employees' practices of service innovation (Orlikowski, 2010; Schatzki, Knorr Cetina and von Savigny, 2001; Schatzki, 2012), and then asked theory-informed questions related to service innovation. In this way, we followed a research process which is explained by Alvesson and Kärreman (2007) as a critical dialogue between theoretical framework and empirical work using a reflexive approach, sensitive construction and interpretive repertoire. A reflexive approach refers to an interpretative, open and locally aware study (Alvesson and Deetz, 2000, p. 113). Sensitive construction implies being surprised and challenged by the empirical material in opposition to having order and control (Alvesson and Kärreman, 2007). Interpretive repertoire refers to combining theories in order to view different perspectives and understand the results from different point of views (Alvesson and Kärreman, 2007, p. 1273). The units of analysis were service innovation projects. Our goal in questioning employees and studying service innovation projects was to investigate what the employees' do, what types of problems employees solve, what kinds of tools are used, and how the actors interact.

Since we also wanted to use theory-informed questions, we used a semistructured interview guide that was designed according to the new service development practice framework suggested by Froehle and Roth (2007). This framework consists of three levels of practices. On the highest level, Froehle and Roth (2007) distinguish resource- from process-oriented practices. Resource-oriented practices are subdivided into intellectual, organizational, and physical resources, whereas process-oriented practices are subdivided into design, analysis, development, and launch stages. 
To identify the service-innovation practices within each dimension, multiple interviews were necessary. The theory-informed interview guide reflected all of the service innovation management practice dimensions suggested by Frohle and Roth (2007). To obtain concrete and specific answers about service innovation, the informants were asked to select two service innovation projects that had been carried out in their firms, and they were asked open questions about the practices in the aforementioned dimensions. Thereafter, the employees were asked several closed follow-up questions (e.g., related to whether specific tools or measures were used) to obtain a more in-depth and complete understanding. We also asked whether the management practices for these projects were representative of the firm's normal practices, and whether or not the informant believed the practices were successful. This theory-informed top-down approach following Froehle and Roth (2007) is relevant to understanding how service innovation is linked to managerial processes, organizational structures, and strategy. The openended practice reflects a bottom-up approach, in which the starting point is the identification of the employees' practices.

\section{Cases and data collection}

The study is based on five scale-intensive service firms. The selected firms operate in both business-to-consumer (B2C) and business-to-business (B2B) markets, and they all provide services both to other firms and to consumers. The five firms provide different types of scale-intensive services: three firms provide financial and insurance services, one firm provides telecom services and one firm provides logistics services. All of the firms claimed in their annual reports that innovation was of strategic importance for the firm. Thus, we expected that the in depth study of the firms' innovation practices would offer opportunities to learn how employees responsible for service innovation in scale-intensive services work, and how managers facilitate service innovation work in these firms. All of the firms were also successful in the market and have expanded beyond their national borders to more than three countries. To preserve anonymity, in this paper, we refer to the five firms as 'Alpha', 'Beta', 'Gamma', 'Delta', and 'Epsilon'. 
Table 1. The list of five scale-intensive service firms, included in the research

\begin{tabular}{|c|c|c|c|c|}
\hline Firm & $\begin{array}{l}\text { Number of } \\
\text { employees }\end{array}$ & $\begin{array}{l}\text { Type of services } \\
\text { provided }\end{array}$ & $\begin{array}{l}\text { Annual } \\
\text { turnover (2010) }\end{array}$ & Informants \\
\hline Alpha & 13500 & $\begin{array}{l}\text { Financial, banking, } \\
\text { insurance }\end{array}$ & $f^{*} 4.24$ billion & $\begin{array}{l}\text { Top/Line/Unit managers: } 1 \\
\text { Innovation managers: } 1 \\
\text { Experts: } 2\end{array}$ \\
\hline Beta & 20000 & $\begin{array}{l}\text { Logistics, } \\
\text { transportation }\end{array}$ & $f^{*} 2.41$ billion & $\begin{array}{l}\text { Top/Line/Unit managers: } 1 \\
\text { Innovation managers: } 1 \\
\text { Experts: } 1\end{array}$ \\
\hline Gamma & 2221 & $\begin{array}{l}\text { Financial, banking, } \\
\text { insurance }\end{array}$ & $f^{*} 5.16$ billion & $\begin{array}{l}\text { Top/Line/Unit managers: } 1 \\
\text { Innovation managers: } 1 \\
\text { Experts: } 1\end{array}$ \\
\hline Delta & 30000 & Telecom & $£^{*} 10.1$ billion & $\begin{array}{l}\text { Top/Line/Unit managers: } 4 \\
\text { Innovation managers: } 2 \\
\text { Experts: } 1\end{array}$ \\
\hline Epsilon & 4300 & Insurance & $£^{*} 1.95$ billion & $\begin{array}{l}\text { Top/Line/Unit managers: } 2 \\
\text { Innovation managers: } 1 \\
\text { Experts: } 1\end{array}$ \\
\hline
\end{tabular}

* Values converted into British pounds using average exchange rates from (2010).

Between three and five employees at each firm were interviewed. The selection of informants followed a snowball sampling procedure. We first asked the firm to appoint an employee who had a central role in the firm's innovation activities, and conducted an in-depth interview with him/her. During the interview, this informant was asked to appoint other key-informants with central roles in the firm's innovation activities. As a result between three and seven employees were interviewed in each firm. The interviews were conducted in Norway in 2011 and 2012. Each interview lasted between 1 and 2 hours. The interviews were recorded and transcribed as text. To reflect the overall innovation practices of the firms and the practices of internal employees, interviewees with different roles and from different firm levels were chosen, including managers, project managers, and IT specialists. The main commonality between them was that they were involved in service innovation. The interviewees were selected by representatives from the firms in dialogue with the involved researchers. In this process, the main selection criterion was their involvement with existing or previous service innovation projects, while also obtaining triangulation of data sources since several employees within the same company were expected to cast different lights on the service innovation work. The cross-case comparisons were performed to obtain validation and generalizations of our findings. 


\section{Coding and analysis}

The data was coded using NVivo, the first iterative coding according to what the informants stated that they did when working with service innovation and then we also coded according to the predefined-structures following the service innovation management practices dimensions suggested by Froehle and Roth (2007). We started to code the data during the process of interviewing. The data were examined relative to the research questions, with specific consideration of how employees undertake service innovation. While interviewing those who were involved in and managed the service innovation projects in the studied firms, we learned their background and characteristics. Iterating between in-depth analysis of the empirical findings from each firm and comparisons across the firms and connections to the literature (Alvesson and Kärreman, 2007), we identified that the internal employees in charge of the service innovation projects were all former consultants and professionals with long experience from professional service firms. Throughout the interviews and during the data analysis process, we clearly observed that the internal service innovators had previously worked as professionals in other PSFs, and that they had different backgrounds and roles compared to other employees in their companies. We thus coded our collected material according to this literature (Alvesson and Karreman, 2006; Anderson-Gough et al., 2000; Greenwood and Empson, 2003; Løwendahl, 2005; Swan, Newell, Scarbrough and Hislop, 1999; von Nordenflycht, 2010), emphasizing altruistic services, autonomy, networking, informal management processes, and cat herding. Using these themes to explore the data, we found variations within each theme, which are reported in the Findings section and further analysed in the Discussion section. The material and our analysis was thoroughly discussed and presented in Power Point to selected employees and managers at the firms through a workshop, to validate the veracity of the data and enhance the trustworthiness of the analysis (Lincoln and Guba, 1985).

\section{FINDINGS}

In this section, we first expose the professional backgrounds of the employees in charge of the service innovation projects, explain the organizational belonging of the employees involved in service innovation, and then briefly describe how the service innovation projects generally proceeded, and expose the different types of service innovation projects (i.e., incremental and radical). After providing these contextual descriptions, we show that how the employees work is in line with the understanding of how PSFs work: i) how professionals work reflects the understanding of altruistic service innovation, 
in terms of ii) having autonomy and iii) networking, and its managerial implications, including iv) management processes and v) wild cat herding.

\section{Characteristics of service innovation}

\section{Employees in charge of service innovation projects}

The professional backgrounds of the "service innovators" differed from the primary fields of their companies and from the particular scale-intensive services provided by their companies (i.e., telecom, finance, insurance, or logistics services). This fact was in contrast to the background of other employees at these firms, who represented the firms' core businesses.

These findings are exemplified by several quotes from employees in the different firms. For example, the director of Strategy and Innovation at Epsilon, in charge of service innovation projects, explained:

"I don't have an insurance background. I have worked in a business lab. I have worked in auditing, in adult learning, in many different jobs. I have worked as a pedagogical consultant, in marketing, and I have a Masters in Management and Organization from CBS. I have a mosaic background..."

At Gamma, a person working across the entire company with the title "Innovation Captain" explained that, before being asked to work in their new position:

"I had a Masters degree in Innovation Management and I had worked for the Idea Laboratory for 5 years as an Idea Astronaut, facilitating business processes. Before [that position], I had worked as an Innovation Consultant at a leading consumer goods company, facilitating, prototyping and developing ideas for management..."

Likewise, a business developer at Alpha in charge of their youth segment explained her background before joining Alpha:

"I had worked for 3 years as a consultant at a small company called "Sun Talk". There, I worked with innovation processes for large companies. Now, I am on the inside. I previously have worked with banking services, although as a consultant, and have managed the innovation processes for companies."

These employees had backgrounds from neo-PSFs, such as management, $\mathrm{IT}$, business modelling consultancy, and business process consultancy (von 
Nordenflycht, 2010), and had started their careers in consulting or business development at other firms.

The everyday work of these middle managers, business developers, IT experts, innovation captains, and facilitators included working with different departments, units, and levels internally within the firm and relating to customers externally. The following quotes illustrate the unique roles of these employees within their firms:

"I am responsible for everything [related to] new services and new ways of working internally in relation to offerings to customers. That does not mean that I work alone, since there are many people who need to be involved in order to realize something; that is my role."

"My everyday work depends on the projects. I receive an inquiry to undertake a project that the units don't have capacity or knowledge to perform. They don't know how to go out and talk with customers. I am thus assigned a project, often with an innovation component. Often it is incremental innovation, something substantially new, and then I make a project design with inherent customer innovation... a good project manager here is someone who knows people internally to gain organizational support, which is extremely important."

In contrast, other employees were described by how they had been groomed and socialized into the organization as 'banking people', 'insurance people', 'engineers', etc.

\section{Organizational belonging and service innovation}

The employees responsible for and actively involved in service innovation within these scale-intensive firms were all positioned differently in their respective organizations. Regardless of whether the employees were part of the business development section, innovation and strategy unit, innovation and research department, IT department, project management group, or belonged to a specific long-term development project, the work and activities for service innovation were very similar. Service innovation projects were either explicitly demanded (due to needs identified by other units) and channelled to the 'service innovator' in charge, or the needs were identified directly by the service innovator. As aforementioned, these service innovators all had earlier work experiences from PSFs, which motivated us to label them as 'internal professionals'. 
The projects generally proceeded as follows. Internal professionals initiated projects based on identified needs, while focusing on and involving end customers. To ensure support and convince decision makers, the internal professionals followed their own methods according to experience, used internal systems if needed, made cost estimates or 'guestimates', made PowerPoint presentations, mock-up models, or initiated pilot applications, and talked with and involved others internally. Finally, the internal professionals divided work by involving internal units (e.g., IT, front-end employees, and back-office employees), while collaborating with others externally (e.g., agencies, researchers, partners, and suppliers). An 'Innovation Captain' summarized the internal involvement and types of resources allocated to the service innovation project as follows:

"The incremental service innovation is my responsibility, the programming in Expression (software) is "Berit's" responsibility and print is "Tor". I work with them and make a suggestion for [the] progress plan."

Thus, the internal professionals had roles as project managers for the ad-hoc teams that they initiated and led. The other participants represented fields of expertise from other departments.

Service innovation projects could be categorized as incrementally or radically new market service innovations. As an example of an incremental service innovation, we consider the 'business portal'. This B2B service was developed by Gamma, which implemented incremental service innovations to meet customer needs. A manager at Gamma explained:

"Several independent advisors had a lot of objections to the [business portal] system. We worked to improve the business aspect of the portal system. We drove the project through 67 deliveries to improve customer value. This time frame was untraditional because, in most projects, it will take us a year to have a new solution. Here, we used incremental development, continuous input, and frequent, small efforts..."

The business portal is a typical example of an incremental service innovation in which professional expertise was used for project management. Some of what was previously used by business customers as professional expertise (e.g., an intricate understanding of the pension systems, new legislative impacts, and differentiated pension schemes) was integrated into the system and automated. 
A good example of a radically new to the market service innovation is the Digital Postal Service (DPS). DPS is a new national digital postal system that allows private businesses, public authorities, and private persons to send post digitally. The DPS system reduces distribution costs and increases the efficiency of customer processes to other businesses. DPS is a solution that will manage all formal and informal documents, such as health information, insurance papers, information from local authorities, and receipts, with a higher security requirement than e-mail. The manager of DPS explained:

"We started with the physical value chain of postal services, what the Postal Services offer as physical post distribution. There are a lot of similarities between the systems - the distribution of documents from $A$ to $B$, things to be added-and the core is similar. The core in the customer segment is similar, too. The traditional core customers of the Postal Services, such as the energy services, telecom services, and public sector, have a lot of documents to be distributed. So, in relation to Osterwalder's business model, we differentiate ourselves with respect to how we sell, how we serve these customers, and where we wish to exploit the digital service. We have worked with many large business customers regarding direct services. Middle-sized businesses will be served through partner contracts, similar to software contracts, in which there are integration points... Small business customers will have self-service... We have some advantages, and one is electronic ID. One has to be $100 \%$ sure of what one gets as a user... In Norway, we have come far with electronic ID... The rest of Europe and the USA have not come that far yet..."

Because it is a radical service innovation, DPS was organised as a large project that has spanned over several years, involving 20 people. Apart from two sellers, all of the project participants have their background from management, IT consulting, and business modelling consulting.

\section{Providing altruistic service innovations}

An important dimension of professionals is related in literature to the strong norms that guide their conduct. These norms, organizational requirements, client needs and self-interest can pose a dilemma for the professional. It appears that professionals continue to abide to the norms of their professions also when they are sole representatives of their profession and employed by big firms such as scale-intensive service firms. The professionals consequently bring with them a different perspective that has a bearing on the way they interact with innovation processes in the scale-intensive service firms observed. Whereas scale-intensive firms focus on standardization to 
harvest scale-advantages, the internal innovation professionals maintain a different perspective critical for the new service development. A manager at Gamma gave the following example of providing services while exploring in-house service innovation:

"Service innovation is a nice concept that should be a primary focus; this opinion is shared by most people in our organization. Innovation is often associated with our delivery of new products. Service innovation implies that we consider everything-business processes, automation, and off-shoringwhile also remembering customer involvement and satisfaction."

Service innovation, in which customers are put in the front seat, was a common denominator at all five firms. A Gamma manager explained:

"We focus on two axes: what is most important to our customers, and where we have the most volume. Then, we identify three areas that are high in both axes-in value and volume-and we choose those three areas... Our new vision is: "Our customers recommend us"."

The service innovation entails substantial digitalization and automation in $\mathrm{B} 2 \mathrm{C}$ and $\mathrm{B} 2 \mathrm{~B}$ relationships. A typical service innovation in B2C was explained by a business developer in Alpha as:

"... a service concept on Facebook where our advisors help you with your first home."

To achieve scale advantages on their services, the firms emphasized replication and repetition, often by enabling their services through ICT. This goal of providing service innovations was seen as different from the goal of other employees, who had more of a "trade" focus that was product- rather than customer-oriented. This difference can be illustrated by the following quotes:

"...they don't see the customer perspective, and then innovation projects don't fit in such a system..."

"...it is not that strange, since banks and insurance companies write pages up and down about the products they have. So, they are very productoriented and not that customer-focused..." 
We understand these findings as providing altruistic service innovation. Having responsibility towards the client by protecting their interests is referred to as altruistic service (Løwendahl, 2005) or trusteeship (Greenwood et al., 2005). Our findings show that this principle is used for service innovation and we thus found altruistic service innovation in scale-intensive firms.

\section{Professionals' work}

\section{Having autonomy}

We next consider how professionals provide their work for service innovation. In the case of Alpha, the work involves operative authority in business development, autonomy in service development, and obtaining new ways of collaborating internally. A business developer explained:

"[Having operative autonomy and authority] is a lot about process methodology, building projects, and making people communicate.... have obtained a lot [of autonomy] because people want to collaborate when we have a nice framing. I let others take credit for projects. I don't need to put my own name on things, because I really think that I will get more done over time if those who are supposed to do the job are put in front..."

According to our findings, it seems that the professional has autonomy due to their expertise, or they take operative autonomy by following their own process and developing the project as they see most fit. A manager in Beta explained:

"We started by setting up some of the elements that would be delivered to the customer. We spent a lot of time evaluating... what we actually have, what we cannot do, and what we can obtain externally. Then, the process was to develop the concept, develop an outline, and start with a business model. Rather early [in this process], we proposed a solution to the corporate management at Beta. Instead of using Power Point, we created something that the corporate management was not used to: a descriptive memo with pictures and stuff, demonstrating, "This is our challenge, this is what Beta can solve, this is in line with digital communication, this is the start of our business model, and we think that Beta can earn money with this."

Another Beta employee explained regarding operative authority:

"We have had extremely free reins. It is not like they steer what we do." 
Following the norms of autonomy, there were professionals that even took risks on behalf of the company. A Beta employee said that, in relation to the service innovation project:

"[In terms of] risk profiles, we need to take some risks."

The findings show that the professionals have autonomy and operative authority while performing their organizations' innovation activities, as long as they report to relevant management and involve other employees. The autonomy of the professionals is legitimized by their competence in their particular area of expertise and how well they perform their work. In these scale-intensive firms, we found that the professionals had a high level of operative autonomy and authority.

\section{Networking}

In some of the companies, internal networking was important for ensuring that the service innovation project would be realized. A Gamma employee explained:

"Networking and creating ownership is extremely important. Even with the top manager in Sweden, with 400,000 customers, even she said yes. There is so much power. A good project internal manager is one who knows people, and networking is extremely important; excessively important."

Others emphasized external networking with existing and potential customers. A Beta manager explained:

"[We talk to customers], first and foremost, because decision-making processes in these kinds of large companies require that we have a relationship [with them]... I think that it helps to talk with them, to have a relationship [with them], so that they will buy services that we will have to work with. Also, it is important for us to listen to their needs."

Both internal and external networking as proactive activities was important for others. An employee at Alpha explained:

"I have "followed the book," but it has been extremely demanding. It is as if my job is a "talking" job, and I go around and talk and talk, and I get so tired of my own voice. I meet people and often I'll ask, "Why don't you talk with him? Why don't you know each other?" and they'll answer "I have never 
talked to him," and I reply "But, I know that he is sitting and working on exactly the same things as you do!" I take it for granted that people collaborate; if they don't, then we won't make it... I have faced a lot of challenges and have made communities work together that have never worked together before. For instance, [there are] two different external agencies that do the same job... I have intervened and said "This is not working, you have to do the same thing." I have even tried to make these two agencies collaborate on my project..."

Internal networking is used by professionals to involve other employees in the service innovation project and to ensure that the project will be realized. External networking is related to understanding customer needs and building the customer relationship. This is in line with PSF literature finding that successful professionals learn and display knowledge and appropriate behaviour through networking (Anderson-Gough et al., 2000). Research has shown that networking and knowing who to contact, such as direct person-toperson contact, is important in service firms and for knowledge creation and innovation (Hydle and Breunig, 2013; Swan et al., 1999). A personalization method involves building and using informal social networks between people in order to create and deliver services which is called a personalization strategy by Hansen et al. (1999). In these scale-intensive firms, internal and external networking was part of the service innovation.

\section{Managing innovation processes}

\section{Using management processes}

When inquiring about the service innovation processes, all of the reviewed firms had formal processes, although they were used to varying degrees. A manager in Delta explained:

"The unit I work in is the one that owns the innovation process at Delta, and I am the operative owner of that process. The innovation process at Delta is a line duty, so it is line management. [The process] starts with something happening: a new technology is introduced, or there is a customer need, or we see gains in a market that we want a share of, or someone had a great idea in the shower that morning. These ideas come from all levels. Then, we start the innovation process. At Delta, we have very strong milestones, where we make decisions about whether a project can continue or not, if it will get Capex funding or not, those kinds of things..." 
Regarding a highly visible service innovation project at Delta, we asked whether the project was a standard Delta project and how it went through the decision gates. The project manager explained:

"Yes, we went through those, but not as a standard project, because it was more of a collaborative project than an internal development project."

Although interviewees reported that formal processes are used to develop new services at Delta, the formal processes at Gamma are merely used to legitimize projects. A Gamma innovation manager explained:

"There is a steering committee for all of the projects that I lead... I put forward a document to them and state what we are going to do, what the solution is, and what we are changing, and I provide a gross prototype... When I presented [this idea] to them, the steering committee decided that it was a good idea... [The decision was based on] a mixture of logical arguments and ethos-our competitor had done it-and pathos-we can't send this out. In the end, they said yes, do it."

In relation to the formal Gamma process, he explained:

"Looking at our intranet pages, you can see our development process, very generally: how we do it, and what we structurally intend to do. The process is very clear about what to do, but what happens before [the formal process] is random..."

In contrast to the standard processes at Delta and Gamma, professionals working with service innovation at Beta and Alpha made their own processes for service innovation projects. A business developer within Alpha explained:

"I don't draw up a process and follow it from A to Z. I take it a bit more on a feeling. However, I am very strict in every meeting, coffee talk, workshop, or presentation. I know exactly what I want and why I do it this way. I have always thought through every single step, but it is not like I make a large project plan. I don't have a real project plan, although I probably should have, but I do have a few milestones, some visual drawings that show how we could do it. But, this approach is really unorthodox. People have asked, "Where is the project plan? Where is the mandate?" And I respond: "I don't have any" (laughter)..." 
These findings show that the firms have formal processes, but the professionals do not necessarily completely comply with them for service innovation projects. Some professionals even make their own processes and follow their own logic. On the whole this practice is different from the practice prescribed to New Product Development (NPD). The normative NPD literature suggests that firms should implement a formal development process with pre-defined stages and go/kill criteria (e.g., Cooper, 2008). Overall, it appears that the professionals in our cases are used to enjoying autonomy and, thus, find new opportunities and solutions that are not provided by the predefined formal processes. Our findings, thus, are in line with the PSF literature stressing that with professionals informal management processes may be more useful than formal rules and systems (von Nordenflycht, 2010).

\section{Herding wild cats}

During the service innovation projects, the professionals may convince others, often their managers, and gain support for their ideas. Other times, professionals believe so strongly in their ideas that they leave the firm. As a middle manager in Beta explained:

"Eric [and I] came from the outside... we are not "Beta men"... To make a structure and have acceptance all the way from the top is unique. All honour to Beta for daring to be that resilient; it is a success story in itself that we managed to make this kind of project with such a structure."

The results show that, in these companies, innovative service work involves convincing other employees and gaining top management backing, financial funding, and the freedom to use and involve people from different parts of the companies. Regarding managerial support, an Alpha employee explained:

"I almost had to present things to the corporate management before Christmas, but then they decided that I did not need to present the project to them again, only to the director of my division..."

A project manager at Beta explained managerial support and how to achieve self-management within a large organization:

"The best practice is to involve the CEO so that he believes in you, because he talks to the Board of Directors, etc." 
Regarding financial support, an employee working with service innovation at Beta explained:

"Beta stands for confidence, which is about quality. People rely on Beta, which is our strength. Beta is a large organization with weight. When Beta decides to do something, Beta has the necessary funding to make it happen."

During our interviews we also encountered two professionals at different firms who were central for service innovation projects at their firms, but who quit their positions to work even more with service innovation. One started a service innovation position with another company. About the initial company, he said:

"There is knowledge in the company, but nothing about innovation. We have a lean unit, and they continuously seek to improve the company... Implicitly, they deal with incremental innovation, development, and service maintenance, but [that approach] does not satisfy my understanding of an innovative business."

The other individual started a business as an entrepreneur:

"Idea creator and innovator: that is what I am. I am an entrepreneur. I started building my own services and business models. It is all about risk profiles. I accept more risks."

These two employees demonstrate how professionals who do not want to be stuck between the enabling and restricting factors of being part of largescale intensive firms leave to other firms or start a competing business. The findings are similar to what the PSF literature refers to as 'herding wild cats' (Løwendahl, 2005). For our scale-intensive firms, the cat-herding challenge is to enable professionals to develop successfully and implement service innovation projects within certain organizational limits.

\section{DISCUSSION}

In this section, we discuss our findings in relation to the theory and suggest future research. Based on our findings we offer three propositions in the following section. 


\section{Internal professionals (P1)}

The service management literature (e.g. Johne and Storey, 1998) suggests that, because services are often produced and delivered simultaneously, frontline employees in service firms obtain unique knowledge about customer needs. Hence, several authors suggest that it is particularly important to involve front-line employees in service innovation (e.g. de Brentani, 2001). Our findings also suggest that front-line employees are often involved when new scale-intensive services are developed. However, in the scale-intensive service firms explored in this study, the front-line employees seemed to have had a more retracted role than prior service innovation studies indicate. Front-line employees were consulted about specific questions, but did not have a role during the entire service innovation process. Most of the in-house employees that participated during the entire service innovation process were co-workers with specialized knowledge, a group referred to as professionals (Løwendahl, 2005). These internal professionals had formal roles as experts, facilitators, project managers, innovation captains, and innovation directors. Based on this observation, we suggest that internal professionals play an important role of intrapreneurs when new scale-intensive services are developed.

Our findings also suggest that when the degree of novelty of the new service to be developed is high (i.e., a radical innovation), many additional characteristics may be derived. The professionals take risks, develop and use their own processes, and are more proactive and self-managing. According to the intrapreneurship literature (Hostager, Neil, Decker and Lorentz, 1998; Miller, 1983; Morrison, Rimmington and Williams, 1999; Pinchot, 1985; Pinchot and Pellman, 1999), these features are classic characteristics of intrapreneurs. Thus, by definition (Miller, 1983), our findings suggest that internal professionals operate as intrapreneurs, or in-house entrepreneurs (Altinay, 2005; Geisler, 1993; Honig, 2001; Pinchot, 1985; Rathna and Vijaya, 2009).

Professionalism can be understood relative to the mastery of a particular expertise or knowledge base (von Nordenflycht, 2010), whereas intrapreneurship involves risk-taking, proactiveness, and new innovations (Miller, 1983; Pinchot, 1985; Pinchot and Pellman, 1999). Despite this duality of roles between professionals and intrapreneurs, our findings indicate that professionals are "just doing their job" when they take roles as intrapreneurs. Intrapreneurs are important in developing and creating revenue for companies (Geisler, 1993; Hisrich and Peters, 2002; Hostager et al., 1998; Pinchot, 1985). Thus, professionals are intrapreneurs when they take the initiative to develop radically new services for their own service firm. This conclusion is consistent with Sundbo, who stated: "Intrapreneurship in the classic sense (where an 
individual is responsible for the whole innovation process) is possible and was reported in the interviews, but it is rare" (1997, p. 444). However, our findings show that intrapreneurship is the rule when internal professionals develop radical services.

The experience of being a professional appears to contribute to the employee's solutions, problem-solving abilities, and unique competences when acting in-house in the role of intrapreneur. Our findings extend the existing theory regarding service innovation by demonstrating that professionals who previously worked for PSFs become internal professionals in scale-intensive firms. Thus, we extend Sundbo's taxonomy on the organization and management of innovation in service firms by exposing that the combination of scale-intensive firms with professionals generates employees who act as professional intrapreneurs. Sundbo's taxonomy mainly highlights the role of top managers in scale-intensive firms as intrapreneurs; professionals in PSFs are understood to be engaging in collective or team intrapreneurship. In contrast, our findings expose individual professional intrapreneurs in scale-intensive firms.

Sundbo identifies three paradigms for understanding innovation in service firms, with technology, entrepreneurship, and strategy being the core determinants of innovation (Sundbo, 1997). He considers the technological and entrepreneurial paradigms to be less relevant in service firms, due to limited amount of technological development and the difficulty of managing intrapreneurs. Thus, he follows the strategic paradigm. In the present paper, the service-innovation projects were both $\mathrm{B} 2 \mathrm{~B}$ and $\mathrm{B} 2 \mathrm{C}$, incremental and radical, and involved automation and digitalisation. The internal professionals, as the planned or ad-hoc project managers of the service innovations, acted as intrapreneurs, while they followed and sometimes even went beyond their firms' strategies. Thus, our findings show that all three of Sundbo's paradigms are joined in scale-intensive service innovation. In particular, scale-intensive service innovation involves automation and digitalisation through both incremental and radical services, reflecting the technological paradigm. The project managers are internal professionals who act as hardto-manage intrapreneurs, according to the entrepreneurial paradigm. Finally, the projects are legitimized relative to existing strategy, while sometimes going beyond the firm's strategy. Although these findings are not reported in this paper, they follow the third paradigm of strategy. Thus, in relation to service innovation in scale-intensive firms, our findings show that all of the paradigms are involved and are not mutually exclusive. Future research should investigate whether these findings are also applicable in other scaleintensive service firms. 
Consequently, we offer the following proposition:

P1: Internal professionals act as intrapreneurs when they are involved in the development of radically new scale-intensive services.

\section{Practices of internal professionals (P2) and managerial challenges (P3)} In addition, our findings suggest that the involved professionals use experience from their earlier employment in PSFs that is beyond the focus of the core services delivered by their current firms. Examples of important competence areas that professionals use include innovation management, process innovation, IT, business model design, and business process design. By definition, the professionals appear to have unique competences that are required for innovation projects in scale-intensive service firms. They have an overview of what resources are needed to carry out an innovation project, and they are able to involve and manage relevant internal and external resources in its different stages. For example, in the early stages of a project, the professionals typically involve internal front-line employees and customers to understand the current challenges. In the development stage, they comprise IT personnel to design an IT platform for new services. In the final stages, the professionals often involve customers in testing new solutions. As a result, the professionals are both customer-centric and solutions-oriented managers of the service innovation process.

There were differences in how the service innovation projects were managed by professionals. Following norms of autonomy, some professionals took risks on behalf of the company. Some professionals partly used the internal processes to perform the project or to legitimize the project in the organization. Other professionals created and used their own processes relative to the project. The professionals highlighted the importance of networking internally and externally; however, some were more proactive in reaching out than others. The professionals reported on the duality of enabling and restraining conditions for service innovation within the firms. Two of the informants even left their companies during the data collection period. Some professionals were hard to manage within the firms, whereas others were self-managing. Therefore, we identified all of the typical characteristics of professionals and related managerial implications described in the literature: providing altruistic service, having autonomy, using networking, informal processes, and cat herding. Moreover, previous studies of new concept development within PSFs found a tension between the need for a disciplined corporate approach and individual professional autonomy (Heusinkveld and Benders, 2002). Our findings from scale-intensive firms 
confirm this conclusion: the firms did have formal corporate processes to follow, but individual professionals followed their own operational autonomy and authority.

Our findings show that internal and external networking is important, as is the ability to convince managers and others to follow the internal professionals' ideas. Therefore, we claim that findings related to professionals' work and service innovations are not only of relevance for PSFs, but are also of use for other service sectors that involve professionals.

We explicate these findings in the following two propositions:

P2: The practices of the internal professionals are characterized by altruism, autonomy and internal networking when they are involved in the development of new scale-intensive services.

P3: The managerial challenges when new scale-intensive services are developed are related to informal management processes and cat herding.

\section{CONCLUSION}

This paper contributes to literature on service innovation theory and professional services by extending knowledge of the role of professionals in innovation processes. We believe that not only the specialized knowledge of professionals but also their professional norms are determinants of success in innovation projects and we explicate our findings in three propositions for further research to confirm.

In this paper, we have addressed two research questions: i) How do employees responsible for service innovation work? and ii) how can managers facilitate service innovation work in scale-intensive firms? This study was based on five scale-intensive service firms theoretically sampled to increase the transferability of its findings. There is a growing interest in how firms achieve higher standardization when services are offered globally. In addition, with the trend of increased servitization (as traditional manufacturing firms transform their portfolios of offerings to services), there is a need to improve the understanding of innovation in scale-intensive services. Consequently, the lessons learned from scale-intensive service firms may be applied to a broader set of firms that innovate and offer standardized services.

We combined two research streams, innovation management and PSF theorizing to understand our findings regarding the employees in charge of the service innovation projects when firms develop and launch new scaleintensive services. We conducted an explorative study in five scale-intensive service firms on service innovation and identified how professionals work 
and found that managerial implications were in line with PSF theory, in scaleintensive service firms. Based on the existing literature we identified five characteristics of professionals' work and coded our findings according to: altruistic services, autonomy, networking, informal management processes, and cat herding. Our study develops the understanding of professionals, specifically, as in-house professionals for service innovation, by recording and analysing data on the practice of professionals employed in large scaleintensive firms. The study reveals how the employment of professionals enables intrapreneurial activities and enhances innovation. Moreover, it appears to be particularly relevant to advocate a client-centric external perspective in organizations where the innovation projects are aimed at standardizations such as in scale-intensive service firms.

We extend knowledge on the roles and functions of internal professionals and how they contribute to innovation. Exposing the differences and similarities between the roles of a professional and an intrapreneur, we highlighted the blend of professionals within other service firms. From an innovation management perspective, the challenge for scale-intensive firms is arguably that much of the workforce has been trained to follow specific norms and codes of conduct for the firm. Therefore, professionals from PSFs who can act as risk-taking and opportunity-seeking intrapreneurs are needed to enable and unfold innovation. These findings have important managerial implications: Large scale-intensive service providers aiming to carry out successful innovation activities should endeavour to employ professionals from relevant disciplines, preferably those with experience from PSFs. These professionals should be given the opportunity to act as intrapreneurs. For example, they may be given key roles in the firm's innovation activities and a certain freedom to organize the innovation processes in the way that they prefer.

On a more general level, this study shows how insights from the available literature on PSFs can be successfully integrated with knowledge from other types of organizations, thus emphasizing how PSFs can be viewed as models for several types of modern organizations.

There are obvious limitations to this study, because we conducted only a few interviews in five firms and only found professionals with a consulting background. A more nuanced perspective on how different types of professionals, such as lawyers and accountants, contribute to service innovations in other firms could be beneficial to pursue in further research. Future studies could also follow service innovation projects from their initiation to their launch to customers, or could even shadow internal professionals during service innovation projects. Continued exploration of the 
role of in-house in other firms is important to further nuance the observations presented in this study.

\section{Acknowledgements}

We would like to acknowledge the contribution and involvement of the industry partners; their openness throughout the research project has been an exemplary basis for research collaboration. We also acknowledge the support from the Research Council of Norway and the Center of Service Innovation for this research.

\section{References}

Abbott, A. (1988). The system of professions: An essay on the division of expert labor Chicago: University of Chicago Press.

Altinay, L. (2005). The intrapreneur role of the development directors in an international hotel group. Service Industries Journal, 25(3), 403-419.

Alvesson, M. \& Deetz, S. (2000). Doing critical management research. London: Sage.

Alvesson, M. \& Karreman, D. (2006). Professional service firms as collectivities. In: R. Greenwood \& R. Suddaby (Eds.), Research in the Sociology of Organizations: Professional Service Firms (pp. 203-230). Oxford: Elsevier.

Alvesson, M. \& Kärreman, D. (2007). Constructing mystery: Empirical matters in theory development. Academy of Management Review, 32(4), 12651281.

Amara, N., Landry, R. \& Doloreux, D. (2009). Patterns of innovation in knowledge-intensive business services. Service Industries Journal, 29(4), 407-430.

Anderson-Gough, F., Grey, C. \& Robson, K. (2000). In the name of the client: The service ethic in two professional services firms. Human Relations, 53(9), 1151-1174.

Casadesus, M., Marimon, F. \& Alonso, M. (2010). The future of standardised quality management in tourism: Evidence from the Spanish tourist sector. Service Industries Journal, 30, 2457-2474.

Castro, L.M., Montoro-Sanchez, A., \& Ortiz-De-Urbina-Criado, M. (2011). Innovation in services industries: current and future trends. Service Industries Journal, 31(1), 7-20.

De Brentani, U. (2001). Innovative versus incremental new business services: Different keys for achieving success. Journal of Product Innovation Management, 18(3), 169-187.

De Jong, J. P., Bruins, J. A., Dolfsma, W. \& Meijgaard, J. (2003). Innovation in service firms explored: what, how and why? Zoetermeer: EIM Business \& Policy Research. 
Drew, S. (1995). Strategic benchmarking: innovation practices in financial institutions. International Journal of Bank Marketing, 13(1), 4-16.

Droege, H., Hildebrand, D. \& Forcada, M.A.H. (2009). Innovation in services: Present findings, and future pathways. Journal of Service Management, 20(2), 131-155.

Ellingsen, G., Monteiro, E. \& Munkvold, G. (2007). Standardisation of work: co-constructive practice. The Information Society, 23(5), 309-326.

Fischer, O. A.M., Garrelfs, R. \& van der Meer, J.D. (1993). Innovatie in de commerciële dienstensector. Enschede: Van der Meer \& Van Tilburg.

Froehle, C.M. \& Roth, A.V. (2007). A Resource-Process Framework of New Service Development. Production and operations management, 16(2), 169-188.

Geisler, E. (1993). Middle Managers as International Corporate Entrepreneurs: An Unfolding Agenda. Interfaces, 23(6), 52-63.

Greenwood, R. \& Empson, L. (2003). The professional partnership: Relic or exemplary form of governance? Organization Studies, 24, 909-933.

Greenwood, R., Li, S.X., Prakash, R. \& Deephouse, D. L. (2005). Reputation, diversification, and organizational explanations of performance in professional service firms. Organization Science, 16(6), 661-673.

Hansen, M.T., Nohria, N. \& Tierney, T. (1999). What's Your Strategy for Managing Knowledge? Harvard Business Review, 77(2), 106-116.

Heusinkveld, S. \& Benders, J. (2002). Between Professional Dedication and Corporate Design. International Studies of Management \& Organization, 32(4), 104-122.

Heusinkveld, S. \& Benders, J. (2005). Contested commodification: Consultancies and their struggle with new concept development. Human Relations, 58(3), 283-310.

Hisrich, R.D. \& Peters, P.M. (2002). Entrepreneurship. London: McGraw-Hill Irwin.

Honig, B. (2001). Learning Strategies and Resources for Entrepreneurs and Intrapreneurs. Entrepreneurship: Theory \& Practice, 26(1), 21-35.

Hostager, T.J., Neil, T.C., Decker, R.L. \& Lorentz, R.D. (1998). Seeing environmental opportunities: effects of intrapreneurial ability, efficacy, motivation and desirability. Journal of Organizational Change Management, 11(1), 11-25.

Hydle, K.M. \& Breunig, K.J. (2013). Transnational project work: practices creating knowing. International Journal of Managing Projects in Business, 6(2), 251-273.

Johne, A. \& Storey, C. (1998). New service development: a review of the literature and annotated bibliography. European Journal of Marketing, 32(3-4), 184-251.

Johri, H.P., Cooper, J.C. \& Prokopenko, J. (1998). Managing internal consulting organizations: A new paradigm. SAM Advanced Management Journal, 63(4), 4-7. 
Lacey, M.Y. (1995). Internal consulting: perspectives on the process of planned change. Journal of Organizational Change Management, 8(3), 75-84.

Lacey, M.Y. \& Tompkins, T.C. (2007). Analysis of Best Practices of Internal Consulting. Organization Development Journal, 25(3), 123-131.

Leiponen, A. (2005). Organization of Knowledge and Innovation: The Case of Finnish Business Services. Industry \& Innovation, 12(2), 185-203.

Lincoln, Y.S. \& Guba, E.G. (1985). Naturalistic inquiry. Beverly Hills, CA: Sage. Løwendahl, B.R. (1997). Strategic management of professional service firms. Copenhagen: Copenhagen Business School Press.

Løwendahl, B.R. (2005). Strategic management of professional service firms ( $3^{\text {rd }}$ edition). Copenhagen: Copenhagen Business School Press.

MacCormack, A. \& Verganti, R. (2003). Managing the Sources of Uncertainty: Matching Process and Context in Software Development. Journal of Product Innovation Management, 20(3), 217-232.

Maister, D.H. (1993). Managing the professional service firm. New York: The Free Press.

Menor, L.J. \& Roth, A.V. (2007). New service development in retail banking: construct development and measurement validation. Journal of Operations Management, 25, 825-846.

Miller, D. (1983). The Correlates of Entrepreneurship in Three Types of Firms. Management Science, 29(7), 770-791.

Morrison, A., Rimmington, M. \& Williams, C. (1999). Entrepreneurship in the hospitality, tourism and leisure industries. Oxford: Butterworth Heinemann.

Orlikowski, W.J. (2010). Practice in research: phenomenon, perspective and philosophy In: D. Golsorkhi, L. Rouleau, D. Seidl \& E. Vaara (Eds.), Cambridge handbook of strategy as practice (pp. 23-33). Cambridge: Cambridge University Press.

Pavitt, K. (1984). Sectoral patterns of technical change: Towards a taxonomy and a theory. Research Policy, 13(6), 343-373.

Pinchot, G. (1985). Intrapreneuring: Why You Do Not Have to Leave the Corporation to Become An Entrepreneur (1 $1^{\text {st }}$ edition). New York: Harper and Row.

Pinchot, G. \& Pellman, R. (1999). Intrapreneuring in action: A handbook for business innovation. San Francisco, CA: Berrett-Koehler.

Rathna, K.G. \& Vijaya, T.G. (2009). Competencies of entrepreneurs and intrapreneurs: A comparative study. South Asian Journal of Management, 16(2), 28-46.

Sako, M. (2009). Technology Strategy and Management: Globalization of Knowledge-intensive Professional Services. Communications of the ACM, 52(7), 31-33.

Schatzki, T.R., Knorr Cetina, K.D. \& von Savigny, E. (Eds.). (2001). The practice turn in contemporary theory. London: Routledge.

Schatzki, T.R. (2012). A primer on practices: Theory and research. In: J. Higgs, R. Barnett, S. Billett, M. Hutchings \& F. Trede (Eds.), Practice-based 
education: Perspectives and strategies (pp. 13-26). Rotterdam: Sense Publishers.

Soete, L. \& Miozzo, M. (1989). Trade and development in services: A technological perspective. Maastricht Economic Research Institute on Innovation and Technology (MERIT) Working Paper No. 89-031.

Sturdy, A. \& Wright, C. (2011). The active client: The boundary-spanning roles of internal consultants as gatekeepers, brokers and partners of their external counterparts. Management Learning, 42(5), 485-503.

Sundbo, J. (1997). Management of Innovation in Service. Service Industries Journal, 17(3), 432-455.

Swan, J., Newell, S., Scarbrough, H. \& Hislop, D. (1999). Knowledge creation and innovation: Networks and networking. Journal of Knowledge Management, 3(4), 262-275.

Toivonen, M. \& Tuominen, T. (2009). Emergence of innovations in services. Service Industries Journal, 29(7), 887-902.

Von Nordenflycht, A. (2010). What is a professional service firm? Toward a theory and taxonomy of knowledge-intensive firms. Academy of Management Review, 35(1), 155-174.

Wright, C. (2008). Reinventing human resource management: Business partners, internal consultants and the limits to professionalization. Human Relations, 61(8), 1063-1086.

Wright, C. (2009). Inside Out? Organizational Membership, Ambiguity and the Ambivalent Identity of the Internal Consultant. British Journal of Management, 20(3), 309-322.

Zomerdijk, L.G. \& Voss, C.A. (2011). NSD Processes and Practices in Experiential Services. Journal of Product Innovation Management, 28(1), 63-80.

\section{Abstrakt (in Polish)}

W niniejszej empirycznej pracy badamy zagadnienie pracowników zajmujacych się innowacjami z dziedziny usług podczas tworzenia i wprowadzania nowych usług o intensywnej skali. Próbujemy znaleźć odpowiedź na dwa pytania: i) W jaki sposób pracujq osoby odpowiedzialne za innowacje w usługach?, oraz ii) Jakie sq implikacje dla kierownictwa podczas tworzenia i uruchamiania ustug o intensywnej skali? W tym celu przeprowadzono 21 jakościowych, pogłębionych wywiadów z pracownikami pięciu firm świadczqcych usługi o intensywnej skali. Wyniki tych wywiadów sugerujq, że zaangażowanie wewnętrznych profesjonalistów jest poważnym atutem podczas tworzenia takich usług, oraz że profesjonaliści działaja jako przedsiębiorcy wewnętrzni gdy sq angażowani w tworzenie radykalnie nowych usług o intensywnej skali. Praca ta integruje pojmowanie typowe dla literatury o innowacyjnym zarzqdzaniu z wiedza profesjonalistów z dostępnej literatury na temat firm świadczqcych profesjonalne usługi, ponieważ przekonujemy się, że profesjonaliści w firmach świadczqcych usługi o intensywnej skali występuja jako wewnętrzni przedsiębiorcy. Praca ta poszerza wiedzę na temat źródet innowacji w firmach świadczq̨cych usługi o intensywnej skali, łączqc spostrzeżenia wyciagnięte z badań jak i teorii. 
Słowa kluczowe: zarzqdzanie innowacjami, innowacje dotyczqce usług, usługi o intensywnej skali, przedsiębiorczość wewnętrzna.

\section{Biographical notes}

Katja Maria Hydle is a senior research scientist at the International Research Institute of Stavanger. Her research concentrates on innovation, professional service work, organisational practices and multinational companies.

Tor Helge Aas is an Associate Professor at Department of Management, School of Business and Law, University of Agder, Norway. Dr. Aas has a PhD in strategy and management from the Norwegian School of Economics. He is conducting research in innovation management, management control and strategic management, particularly in relation to the service sector.

Karl Joachim Breunig is an Associate Professor at the School of Business, Oslo and Akershus University College. He received his PhD in Strategic Management from BI Norwegian Business School, and holds a MSc from London School of Economics. Dr. Breunig's research concentrates on topics including: service innovation, management and performance measurements of knowledge work, and internationalization of knowledge intensive firms. 